\title{
PENGARUH MEDIA HIPOSALIN DAN HIPERSALIN TERHADAP RESPON PERTUMBUHAN DAN BIOPIGMEN Dunaliella salina
}

\author{
Oleh \\ Muhammad Zainuddin, Noor Hamid, Luky Mudiarti, Nurcahyo Kursistyanto, Budi \\ Aryono \\ Program Studi Budidaya Perairan, Universitas Islam Nahdlatul Ulama, Jepara \\ Email : zain_mz86@yahoo.com \\ Received January 2017 Accepted March 2017
}

\begin{abstract}
ABSTRAK
Dunaliella salina merupakan kelompok alga hijau yang menghasilkan pigmen (klorofil, karotenoid, $\beta$-karoten). Klorofil dan karotenoid dapat digunakan sebagai zat pewarna aditif, antioksidan, antikanker, anti-aging, dan Immunomostimulan. Faktor lingkungan yang diduga mempengaruhi pertumbuhan sel dan kandungan pigmen $D$. salina adalah salinitas. Oleh karena itu perlu adanya penelitian mengenai pengaruh salinitas terhadap kandungan pigmen (klorofil a, b dan karotenoid), biomassa dan pertumbuhan sel pada $D$. salina. Penelitian ini dilakukan dengan menggunakan metode eksperimen laboratoris di Laboratorium Prodi Budidaya Perairan UNISNU - Jepara. Perlakuan perbedaan salinitas (hiposalin dan hipersalin) memberikan pengaruh secara signifikan $(p<0,05)$ terhadap pola pertumbuhan $D$. salina. Secara berurutan salinitas 20 ppt memiliki puncak pertumbuhan pada hari ke 10 dengan kepadatan $603 \times 10^{4} \mathrm{sel} / \mathrm{ml}$, salinitas 25 ppt pada hari ke 10 sebesar 1081 $\times 10^{4} \mathrm{sel} / \mathrm{ml}$, salinitas $30 \mathrm{ppt}$ hari ke 11 sebesar $1160 \times 10^{4} \mathrm{sel} / \mathrm{ml}$, salinitas $35 \mathrm{ppt}$ hari ke 11 sebesar $675 \times 10^{4} \mathrm{sel} / \mathrm{ml}$, dan salinitas 40 ppt pada hari ke 12 sebesar $857 \times$ $10^{4} \mathrm{sel} / \mathrm{ml}$. Berdasarkan data laju pertumbuhan menunjukkan nilai tertinggi pada salinitas 30 ppt $(p<0,05)$ yaitu $0,163^{\mathrm{d}}$ jam $^{-1}$. Berdasarkan data konsentrasi pigmen menunjukkan salinitas 30 ppt memiliki nilai tertinggi $(p<0,05)$ yaitu klorofil a sebesar $10,961^{\mathrm{C}} \mathrm{mg} / \mathrm{l}$, klorofil b sebesar $3,636^{\mathrm{b}} \mathrm{mg} / \mathrm{ml}$, dan karotenoid sebesar $4,954^{\mathrm{C}} \mathrm{mg} / \mathrm{l}$.
\end{abstract}

Kata kunci : mikroalga, salinitas, pertumbuhan, pigmen, antioksidan.

\begin{abstract}
Dunaliella salina is a group of green algae that produce pigments (chlorophyll, carotenoids, $\beta$-carotene). Chlorophyll and carotenoids can be used as additive, antioxidant, anticancer, anti-aging, and Immunomostimulan. The environmental factor suspected to affect cell growth and pigment content of $D$. salina is salinity. Therefore, it is necessary to study the effect of salinity on pigment content (chlorophyll $a, b$ and carotenoid), biomass and $D$. salina growth. This research was conducted by using laboratory experimental method in Laboratory of Cultivation Study Program of UNISNU - Jepara. Treatment of salinity differences (hyposaline and hypersaline) had significant effect $(p<0.05)$ on growth pattern of $D$. salina. The 20 ppt salinity has a growth peak on day 10 with a density of $603 \times 104$ cells / ml, salinity 25 ppt on day 10 of $1081 \times 104$ cells / ml, salinity 30 ppt day 11 is $1160 \times 104$ cells / ml, Salinity 35 ppt day 11 is $675 \times 104$ cells / ml, and salinity 40 ppt on day 12 is $857 \times 104$ cells / ml. Based on data growth rate showed the highest value at salinity 30 ppt $(p<0,05)$ that
\end{abstract}


is $0,163 d$ hour -1 . Based on the data of pigment concentration showed that salinity 30 ppt have the highest value $(p<0,05)$ that is chlorophyll a of $10,961 \mathrm{c} \mathrm{mg} /$, chlorophyll b equal to $3,636 \mathrm{~b} \mathrm{mg} \mathrm{/} \mathrm{ml}$, and carotenoid $4,954 \mathrm{c} \mathrm{mg} \mathrm{/}$.

Keywords: microalgae, salinity, growth, pigment, antioxidant.

\section{PENDAHULUAN}

\section{Latar Belakang}

Dunaliella salina merupakan kelompok alga hijau yang menghasilkan pigmen (klorofil, karotenoid, $\beta$-karoten). Klorofil dan karotenoid dapat digunakan sebagai zat pewarna aditif, antioksidan, antikanker, anti-aging, dan Immunomostimulan. Pertumbuhan mikroalga dipengaruhi oleh faktor internal dan eksternal. Faktor internal yaitu jenis mikroalga, ukuran dan bentuk sel, dan fisiologi sel, sedangkan faktor eksternal yaitu suhu, pH intensitas cahaya, kimia-fisika dan salinitas. Setiap mikroalga memiliki bentuk penyesuaian yang berbeda terhadap faktor internal dan eksternal sesuai dengan kemampuan toleran mikroalga (Huang et al., 2011).

Salinitas merupakan faktor yang penting dalam pembentukan pigmen, produksi biomassa dan pertumbuhan sel (Adenan, 2013). Penelitian mengenai pengaruh salinitas terhadap mikroalga telah dilakukan oleh beberapa peneliti. Yudiati et al. (2010) melakukan penelitian mengenai pengaruh salinitas terhadap kandungan lipid mikroalga Nannochloropsis sp. Zhila et al. (2010) melakukan penelitian mengenai pengaruh salinitas terhadap kandungan biokimia mikroalga Botryococcus braunii. Gu et al. (2012) melakukan penelitian mengenai pengaruh salinitas terhadap pertumbuhan sel dan produksi lipid Nannochloropsis oculata.

Di perairan laut $D$. salina kelihatan berwarna hijau, tetapi pada kondisi dengan salinitas dan intensitas pencahayaan yang tinggi, mikroalga ini bisa berubah warna menjadi merah dan melindungi karotenoid pada selnya (Dhanam, 2013). Berdasarkan pentingnya pengaruh salinitas terhadap mikroalga dalam pertumbuhan, kepadatan, dan senyawa bioaktif (protein, lemak, karbohidrat, dan pigmen) maka perlu dikaji penelitian mengenai pengaruh salinitas yang berbeda terhadap pigmen dan biomassa pada $D$. salina.

\section{METODE PENELITIAN}

\section{Materi Penelitian}

Materi penelitian ini adalah mikroalga $D$. salina dan menggunakan pupuk Walne yang didapatkan dari Laboratorium Pakan Hidup, BBPBAP - Jepara.

\section{Metode Penelitian}

Penelitian terdiri dari 6 tahap yaitu : (1). Pembuatan media kultur mengacu pada Gunawan (2004), (2). Kultivasi D. salina dalam eksperimen, (3). Penghitungan kepadatan sel mengacu pada metode Isnansetyo dan Kurniastuty (1995), (4). Penghitungan laju pertumbuhan menurut Hirata et al. (1981), (5). Pemanenan 
biomassa $D$. salina mengacu pada (Amini, 2010). (6). Analisis pigmen klorofil a, b dan karotenoid mengacu pada metode Vo (2014) dan Pisal (2005).

\section{Pembuatan Media Kultur}

Stok air laut steril dengan salinitas 32 ppt kemudian diencerkan dengan salinitas yang diinginkan sesuai perlakuan. Pembuatan media air laut dengan salinitas yang diinginkan dalam kultur skala laboratorium $(20$ ppt, 25 ppt, 30 ppt, 35 ppt, 40 ppt). Media kultur yang digunakan adalah dengan menyediakan media 15 botol kultur masing - masing berkapasitas $500 \mathrm{ml}$ yang berisi air laut $300 \mathrm{~mL}$ yang sudah diukur salinitas menggunakan refraktometer sebesar 20 ppt, 25 ppt, 30 ppt, 35 , ppt, 40 ppt. Setiap perlakuan ada 3 pengulangan. Media air laut sebelumnya telah ditambahkan $1 \mathrm{ml} / \mathrm{L}$ pupuk Walne dan $0,1 \mathrm{ml} / \mathrm{L}$ Vitamin disetiap perlakuan dan diberi aerasi.

\section{Kultivasi Dunaliella salina pada Salinitas yang Berbeda}

Kepadatan awal $D$. salina adalah $118 \times 10^{4} \mathrm{sel} / \mathrm{mL}$. Starter D. salina diinokulasikan kedalam masing - masing botol kultur sehingga mencapai kepadatan $10^{5} \mathrm{sel} / \mathrm{mL}$. botol kultur yang sudah diinokulasikan starter $D$. salina ditutup dengan kain kasa yang berisi kapas untuk menghindari media kultur dari kontaminasi udara luar yang berada disekitar kultivan. Pengukuran parameter kualitas media dilakukan setiap hari sekali pada sore hari pukul 15.00 WIB, yaitu $\mathrm{pH}$, DO, dan salinitas agar mengetahui perkembangan dan tidak terjadi kontaminan terhadap mikroalga $D$. salina yang telah dikultivasi.

\section{Perhitungan Kepadatan Sel}

Perhitungan kepadatan (jumlah sel $/ \mathrm{mL}$ ) D. salina diamati dengan cara mengambil sampel setiap hari menggunakan pipet tetes, kemudian dimasukkan kedalam chamber haemocytometer. Selanjutnya dihitung jumlah sel secara langsung menggunakan mikroskop dengan perbesaran 400x dan alat bantu handy counter. Teknik pengenceran dilakukan saat kepadatan $D$. salina sudah tinggi, rumus perhitungannya diadaptasi metode Isnansetyo dan Kurniastuty (1995) sebagai berikut :

$$
\text { Kepadatan }=\frac{N \text { dalam } 4 \text { blok }}{\text { Jumlah blok }(4)} \times 10^{4}\left(\frac{\mathrm{sel}}{\mathrm{mL}}\right)
$$

Keterangan :

$\mathrm{N} \quad$ : Jumlah sel mikroalga yang teramati

\section{Laju Pertumbuhan Dunaliella salina}

Laju pertumbuhan didapat dari jumlah kepadatan sel selama kultivasi mikroalga. Menurut Hirata et al. (1981) rumus laju pertumbuhan mikroalga adalah sebagai berikut :

$$
K=3,22 \frac{\log \left(\frac{N t}{N o}\right)}{t i-t o}
$$


Keterangan :

$$
\begin{array}{ll}
\mathrm{K} & \text { : laju tumbuh (pembelahan sel/hari) } \\
\mathrm{Nt} & \text { : kepadatan sel pada hari } \mathrm{t}(\mathrm{sel} / \mathrm{ml}) \\
\mathrm{No} & \text { : kepadatan awal hari (sel/ml) } \\
\mathrm{Ti} & \text { : waktu ke-t (hari) } \\
\text { to } & \text { : waktu awal (hari) }
\end{array}
$$

\section{Pemanenan Biomassa Dunaliella salina}

Pemanenan dilakukan pada fase stasioner dengan menggunakan modifikasi flokulan yaitu metode pengendapan dengan menggunakan bahan kimia $\mathrm{NaOH}$ dengan masing - masing perlakuan diberi sebanyak 0,3 gram. Pengendapan dilakukan selama 24 jam, kemudian dilakukan pemisahan biomassa dan cairan jernihnya. Selanjutnya biomassa dicuci dengan aquades untuk menghilangkan kandungan garamnya, kemudian disaring dengan menggunakan kain satin dan dilakukan ekstraksi.

\section{Analis Pigmen}

Menurut Vo (2014) dan Pisal (2005) untuk analis pigmen karotenoid menggunakan volume kultur basah. Kultur basah sampel $D$. salina sebesar 0,5 gram disaring menggunakan kertas filter milipore, kemudian dilarutkan pelarut aseton 10 $\mathrm{mL}$ hancurkan dengan vortex hingga homogen. Setelah itu disentrifugasi dengan kecepatan $2000 \mathrm{rpm}$ selama 5 menit. Supernatan dilakukan spektrofotometer. Setelah mendapatkan nilai absorbansinya maka kadar pigmen dapat diketahui melalui perhitungan:

$$
\begin{aligned}
\underset{\text { Kandungan karotenoid }}{(\mathrm{mg} / \mathrm{L})}= & \left(1000 \mathrm{x} \mathrm{A}_{470}-2,770\left(11,75 \mathrm{xA}_{662}-2,350 \mathrm{x}\right.\right. \\
& \left.\left.\mathrm{A}_{645}\right)-81,4\left(18,61 \mathrm{xA}_{645}-3,960 \mathrm{xA}_{662}\right)\right) / 227
\end{aligned}
$$

$$
\text { Kandungan Klorofil a }(\mathrm{mg} / \mathrm{L})=\frac{\left(11.85 \times \mathrm{A}_{664}\right)-\left(1.54 \times \mathrm{A}_{647}\right)-\left(0.08 \times \mathrm{A}_{630}\right)}{\mathrm{Vs} \times \mathrm{d}} \times \mathrm{Ve}
$$

Kandungan Klorofil b $(\mathrm{mg} / \mathrm{L})=\frac{\left(21.03 \times \mathrm{A}_{647}\right)-\left(5.43 \times \mathrm{A}_{664}\right)-\left(2.66 \times \mathrm{A}_{630}\right)}{\mathrm{Vs}_{\mathrm{d}}} \times \mathrm{Ve}$

Keterangan :

$\begin{array}{ll}\text { A470 } & \text { : Nilai absorbansi pada } 470 \mathrm{~nm} \\ \text { A662 } & \text { : Nilai absorbansi pada } 662 \mathrm{~nm} \\ \text { A645 } & \text { : Nilai absorbansi pada } 645 \mathrm{~nm} \\ \text { A664 } & \text { : Nilai absorbansi pada } 664 \mathrm{~nm} \\ \text { A647 } & \text { : Nilai absorbansi pada } 647 \mathrm{~nm} \\ \text { A630 } & \text { : Nilai absorbansi pada } 630 \mathrm{~nm} \\ \text { Ve } & \text { : Volume ekstrak aseton (ml) } \\ \text { Vs } & \text { : Volume contoh air yang disaring (liter) } \\ \text { D } & \text { : Lebar diameter cuvet }(1 \mathrm{~cm})\end{array}$




\section{HASIL DAN PEMBAHASAN}

Mikroalga D. salina didapatkan dari BBPBAP Jepara. Selanjutnya digunakan sebagai stater dalam penelitian ini. Kultur $D$. salina dengan menggunakan pupuk walne pada perlakuan perbedaan salinitas yaitu 20 ppt, 25 ppt, 30 ppt, 35 ppt dan 40 ppt. Berdasarkan hasil pengamatan kepadatan $D$. salina pada perlakuan salinitas 20 ppt (gambar 1) menunjukkan bahwa terjadi fase lag atau penyesuaian dari awal penelitian sampai dengan pengamatan hari ke 3 dengan nilai kepadatan $10 \times 10^{4}-$ $74 \times 10^{4} \mathrm{sel} / \mathrm{ml}$. Fase penyesuaian ditunjukkan dengan nilai kepadatan yang tidak berbeda secara signifikan $(p>0,05)$. Selanjutnya terjadi peningkatan kepadatan pada pengamatan hari ke 4 sampai dengan hari ke 10 dengan nilai $118 \times 10^{4} \mathrm{sel} / \mathrm{ml}$ hingga $603 \times 10^{4} \mathrm{sel} / \mathrm{ml}$ yang berbeda secara signifikan $(p<0,05)$ dan disebut fase eksponensial. Pada pengamatan hari ke 11 hingga akhir penelitian hari ke 13 menunjukkan terjadi penurunan kepadatan sel dari $566 \times 10^{4} \mathrm{sel} / \mathrm{ml}$ hingga $489 \times 10^{4}$ $\mathrm{sel} / \mathrm{ml}$ yang berbeda secara signifikan $(p<0,05)$ dan disebut fase kematian.

Berdasarkan hasil pengamatan kepadatan $D$. salina pada perlakuan salinitas 25 ppt (gambar 2) menunjukkan bahwa terjadi fase lag atau penyesuaian dari awal penelitian sampai dengan pengamatan hari ke 2 dengan nilai kepadatan $10 \times 10^{4}$ $60 \times 10^{4} \mathrm{sel} / \mathrm{ml}$ yang tidak berbeda secara signifikan $(p>0,05)$. Selanjutnya terjadi peningkatan kepadatan pada pengamatan hari ke 3 sampai dengan hari ke 11 dengan nilai $116 \times 10^{4} \mathrm{sel} / \mathrm{ml}$ hingga $1081 \times 10^{4} \mathrm{sel} / \mathrm{ml}$ yang berbeda secara signifikan $(p<0,05)$ dan disebut fase eksponensial. Pada pengamatan hari ke 12 hingga akhir penelitian hari ke 14 menunjukkan terjadi penurunan kepadatan sel dari $1002 \times 10^{4} \mathrm{sel} / \mathrm{ml}$ hingga $746 \times 10^{4} \mathrm{sel} / \mathrm{ml}$ yang berbeda secara signifikan $(p<0,05)$ dan disebut fase kematian.

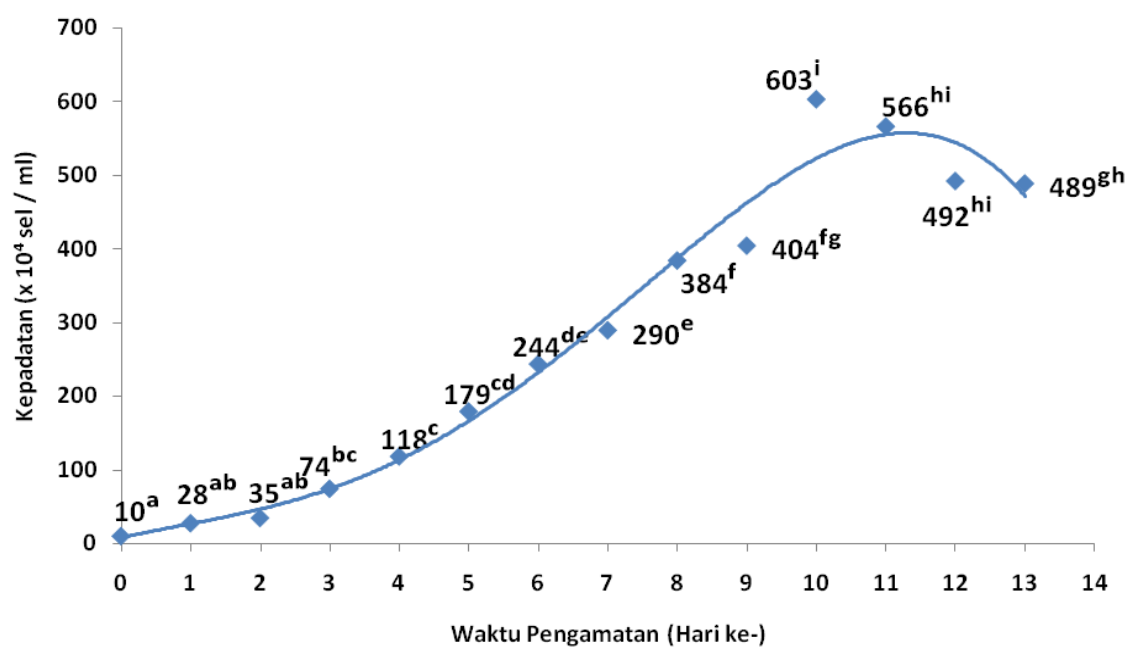

Gambar 1. Pertumbuhan D. salina pada perlakuan salinitas 20 ppt. 


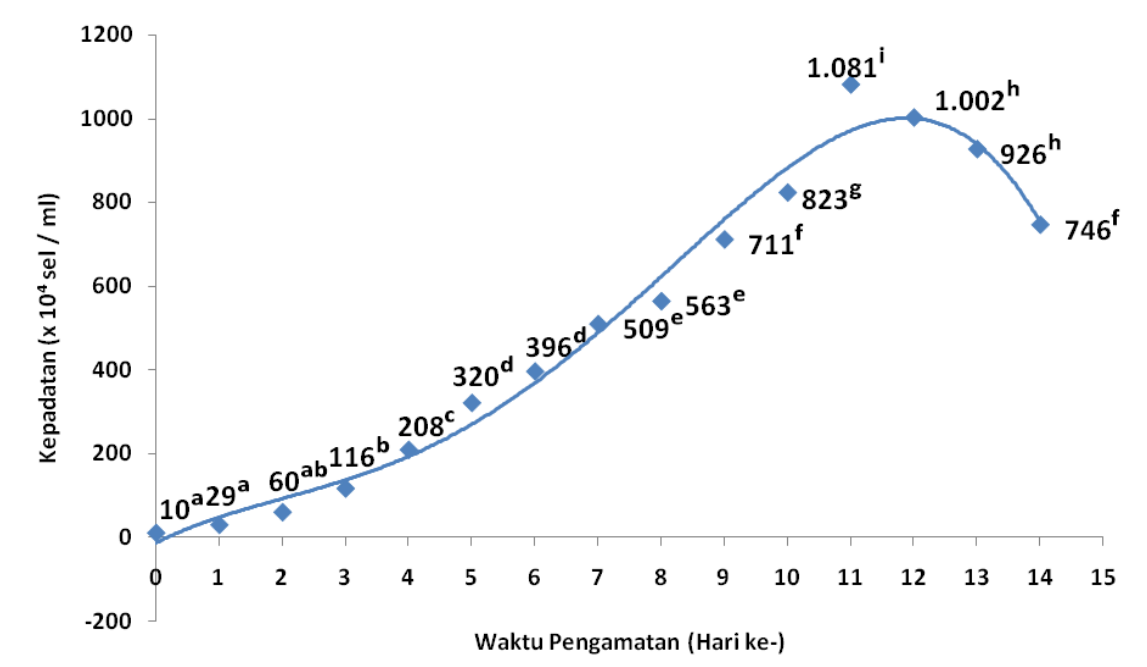

Gambar 2. Pertumbuhan D. salina pada perlakuan salinitas 25 ppt.

Perlakuan salinitas 30 ppt (gambar 3) menunjukkan bahwa terjadi fase lag atau penyesuaian dari awal penelitian sampai dengan pengamatan hari ke 3 dengan nilai kepadatan $10 \times 10^{4}-94 \times 10^{4} \mathrm{sel} / \mathrm{ml}$ yang tidak berbeda secara signifikan $(p>$ $0,05)$. Selanjutnya fase eksponensial terjadi peningkatan kepadatan secara signifikan $(p<0,05)$ pada pengamatan hari ke 3 sampai dengan hari ke 11 dengan nilai $148 x$ $10^{4} \mathrm{sel} / \mathrm{ml}$ hingga $1160 \times 10^{4} \mathrm{sel} / \mathrm{ml}$. Pada fase kematian terjadi penurunan kepadatan sel pada pengamatan hari ke 12 hingga akhir penelitian hari ke 14 sebesar $963 \times 10^{4}$ $\mathrm{sel} / \mathrm{ml}$ hingga $645 \times 10^{4} \mathrm{sel} / \mathrm{ml}$ yang berbeda secara signifikan $(p<0,05)$.

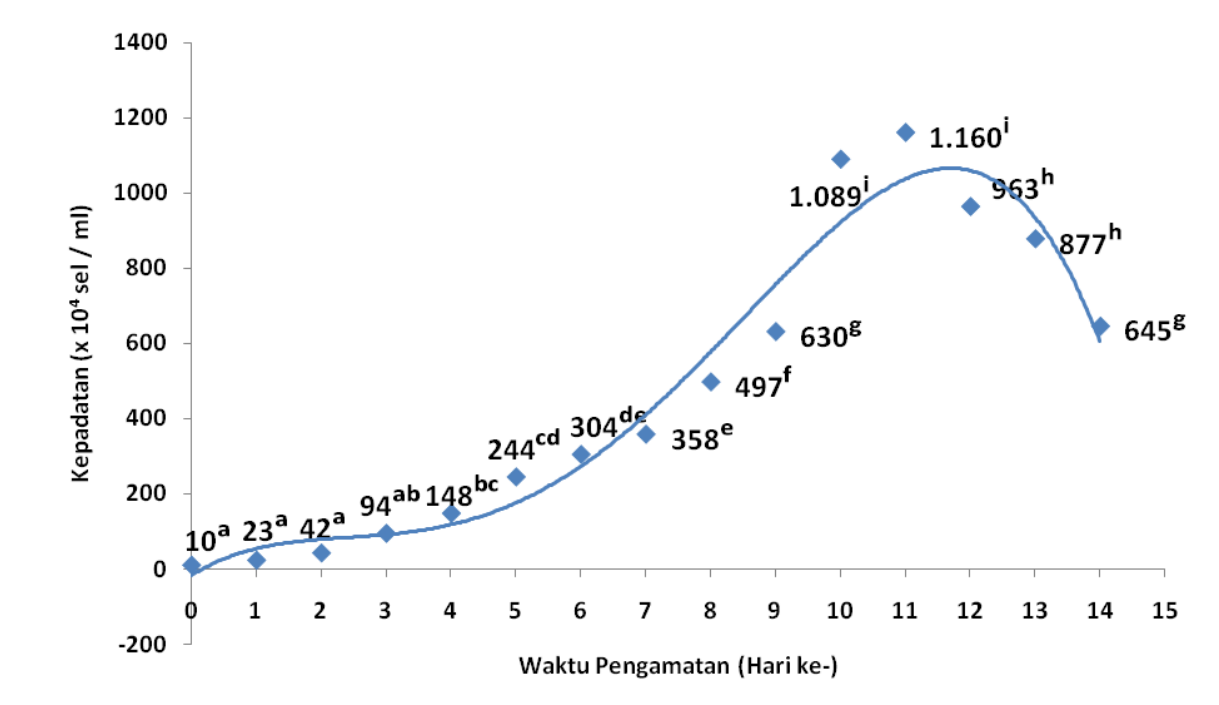

Gambar 3. Pertumbuhan D. salina pada perlakuan salinitas 30 ppt. 


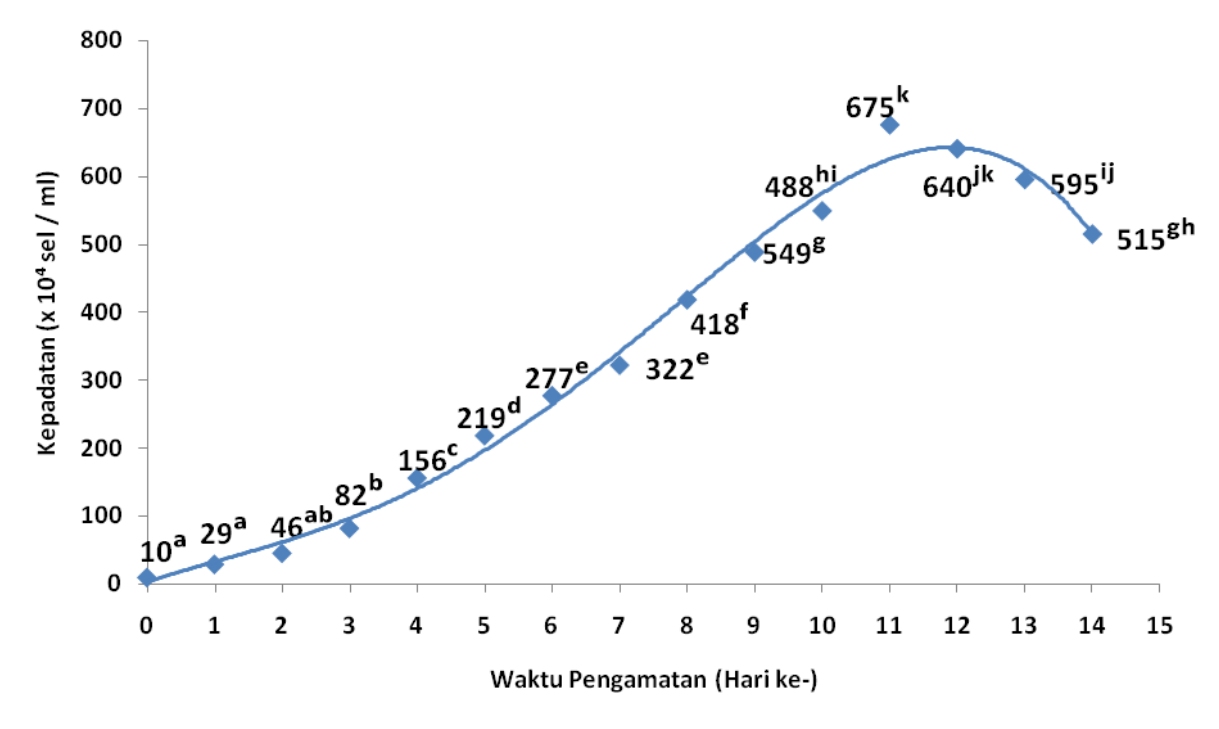

Gambar 4. Pertumbuhan D. salina pada perlakuan salinitas $35 \mathrm{ppt}$.

Perlakuan salinitas 35 ppt (gambar 4) menunjukkan fase lag selama 2 hari dengan nilai kepadatan $10 \times 10^{4}-46 \times 10^{4} \mathrm{sel} / \mathrm{ml}$ yang tidak berbeda secara signifikan $(p>0,05)$. Selanjutnya fase eksponensial terjadi peningkatan signifikan ( $p$ $<0,05)$ pada pengamatan hari ke 3 sampai dengan hari ke 11 dengan nilai $82 \times 10^{4}$ $\mathrm{sel} / \mathrm{ml}$ hingga $675 \times 10^{4} \mathrm{sel} / \mathrm{ml}$. Fase kematian terjadi penurunan signifikan $(p<0,05)$ pada hari ke 12 hingga 14 sebesar $640 \times 10^{4} \mathrm{sel} / \mathrm{ml}$ hingga $515 \times 10^{4} \mathrm{sel} / \mathrm{ml}$.

Perlakuan salinitas 40 ppt (gambar 5) menunjukkan fase lag selama 2 hari dengan nilai kepadatan $10 \times 10^{4}-61 \times 10^{4} \mathrm{sel} / \mathrm{ml}$ yang tidak berbeda secara signifikan $(p>0,05)$. Selanjutnya fase eksponensial terjadi peningkatan $(p<0,05)$ pada pengamatan hari ke 3 sampai dengan hari ke 12 dengan nilai $125 \times 10^{4} \mathrm{sel} / \mathrm{ml}$ hingga $857 \times 10^{4} \mathrm{sel} / \mathrm{ml}$. Fase kematian terjadi penurunan $(p<0,05)$ pada hari ke 13 hingga 15 sebesar $737 \times 10^{4} \mathrm{sel} / \mathrm{ml}$ hingga $636 \times 10^{4} \mathrm{sel} / \mathrm{ml}$.

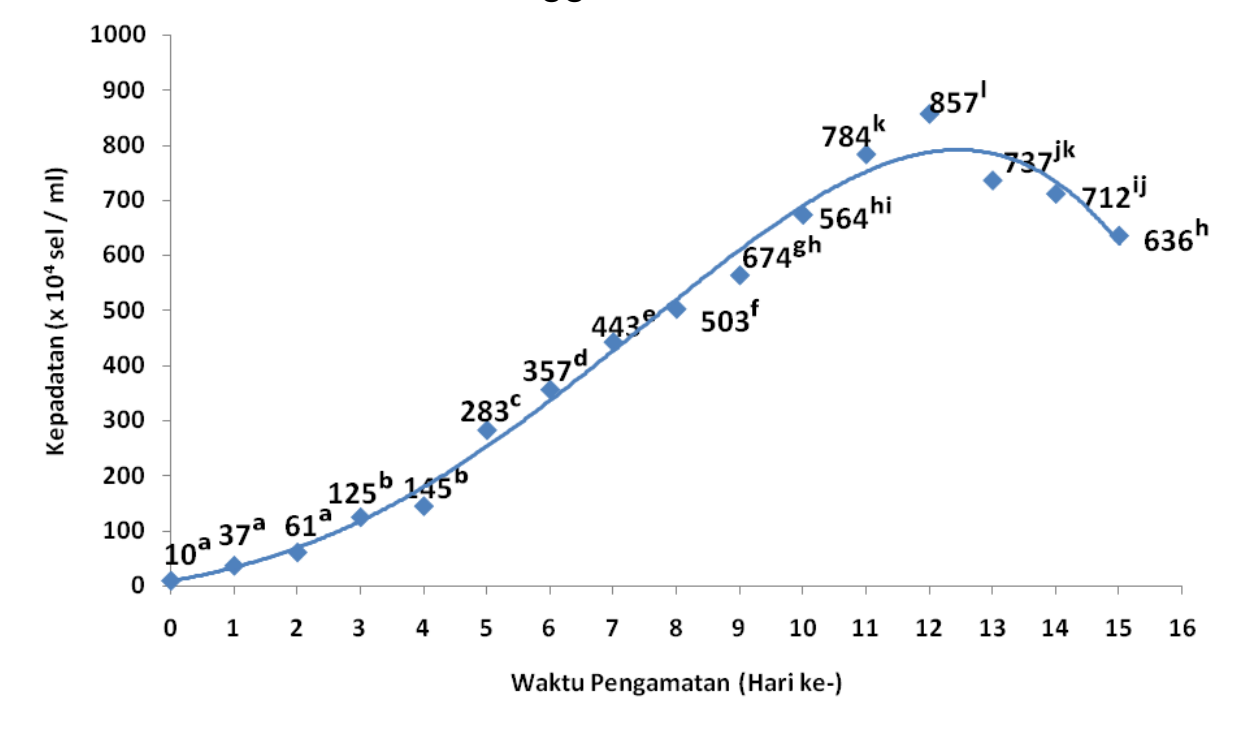

Gambar 5. Pertumbuhan D. salina pada perlakuan salinitas 40 ppt. 


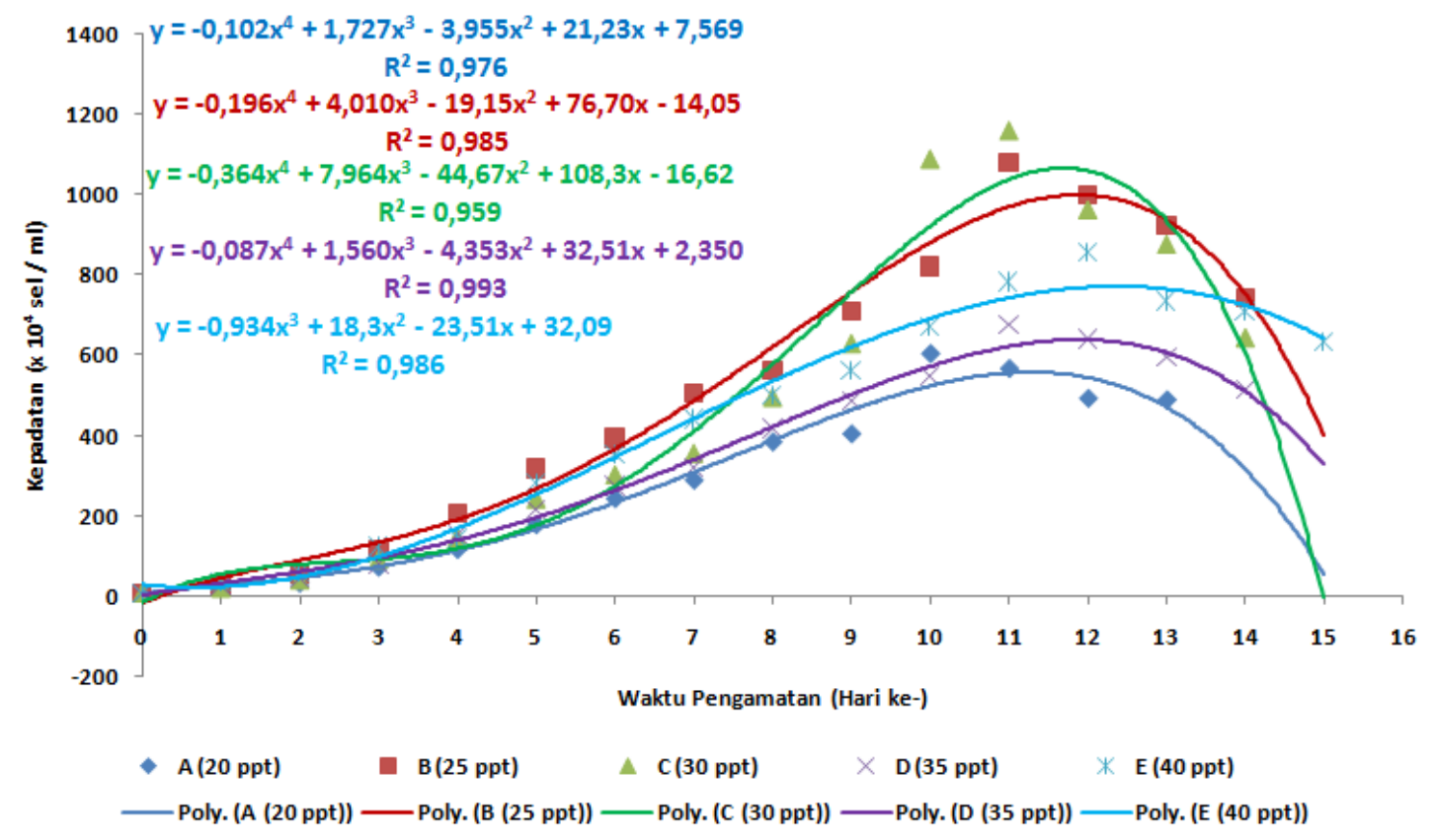

Gambar 6. Pertumbuhan D. salina pada perlakuan perbedaan salinitas.

Berdasarkan gambar 6 menunjukkan bahwa perbedaan salinitas mempengaruhi pola pertumbuhan mikroalga $D$ salina. Garis polynomial terbawah adalah perlakuan 20 ppt menunjukkan bahwa nilai kepadatan dari hari ke 1 sampai akhir penelitian hari ke 15 adalah yang terkecil dari pada perlakuan salinitas yang lain. Sedangkan pada perlakuan 25 ppt pada hari ke 1 hingga hari ke 9 memiliki nilai kepadatan tertinggi tetapi pada hari ke 9 hingga 13 posisi kepadatan tertinggi pada perlakuan 30 ppt. Menurut Erlina (2007), kadar garam yang berubah-ubah dalam air dapat menimbulkan hambatan bagi kultur mikroalga. Salinitas yang terlalu tinggi menyebabkan terganggunya tekanan osmotik kultivan. Menurut Erdmann and Hagemann (2001) dalam Imron et al. (2016) menambahkan bahwa tingginya konsentrasi garam pada media yang didominasi oleh ion $\mathrm{Na}^{+}$dan $\mathrm{Cl}^{-}$dapat menyebabkan terganggunya kesimbangan osmotik yaitu antara bagian dalam sel dengan media hidupnya yang menyebabkan air dalam sel banyak keluar.

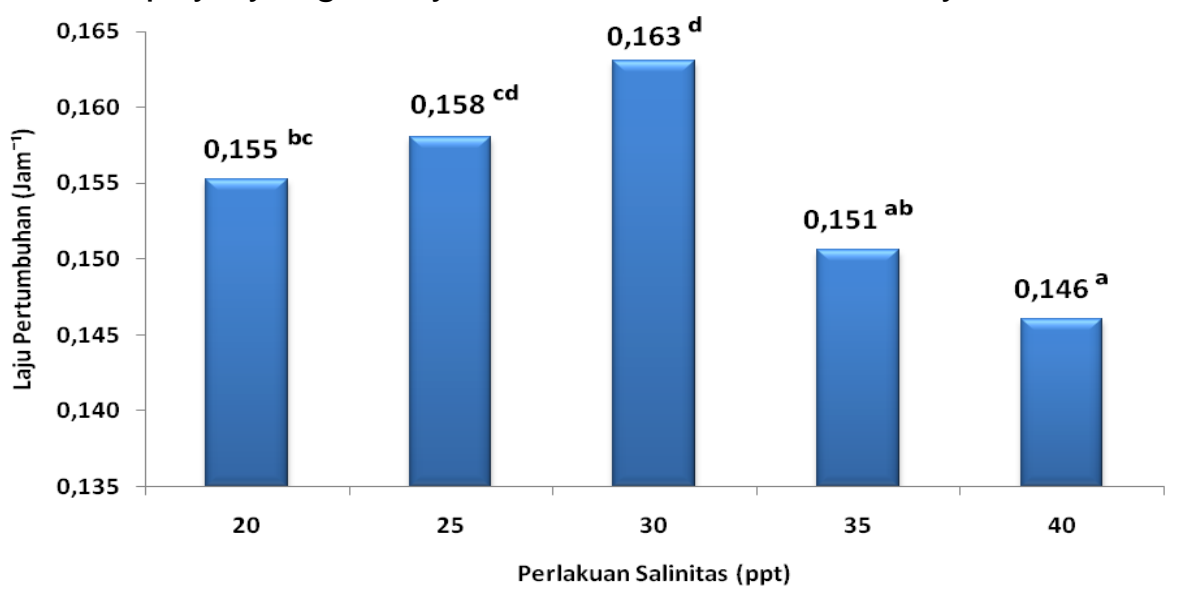

Gambar 7. Laju pertumbuhan $D$. salina pada perlakuan perbedaan salinitas. 
Berdasarkan data laju pertumbuhan gambar 7 menunjukkan bahwa perlakuan media hiposalin dan hipersalin memberikan pengaruh terhadap laju pertumbuhan mikroalga $D$. salina secara signifikan $(p<0,05)$. Secara berurutan perlakuan dengan laju pertumbuhan terendah ke tertinggi adalah perlakuan 40 ppt, 35 ppt, 20 ppt, 25 ppt dan 30 ppt sebesar $0,146^{\mathrm{a}} ; 0,151^{\mathrm{ab}} ; 0,155^{\mathrm{bc}} ; 0,158^{\mathrm{cd}}$ jam $^{-1}$. Berdasarkan gambar 7 menunjukkan bahwa perlakuan salinitas optimal pada $30 \mathrm{ppt}$, semakin rendah salinitas dan semakin tinggi salinitas dari salinitas optimal maka laju pertumbuhan semakin rendah. Faktor yang mempengaruhi laju pertumbuhan spesifik $(\mu)$ adalah kandungan unsur hara yang terdapat dalam media kultur. Menurut Rusyani (2001), terjadi penurunan jumlah sel karena kandungan nutrien pada media kultur berada dalam jumlah yang terbatas. Kandungan nutrien pada awal kultur yang masih tinggi, dimanfaatkan oleh masing-masing sel untuk melakukan pertumbuhan. Peningkatan jumlah sel akan terhenti pada satu titik puncak populasi (fase eksponensial), pada fase ini kebutuhan nutrien akan semakin besar, sedangkan tidak adanya penambahan nutrien selama masa kultur berlangsung sehingga menyebabkan penurunan jumlah sel dalam waktu yang lebih cepat.

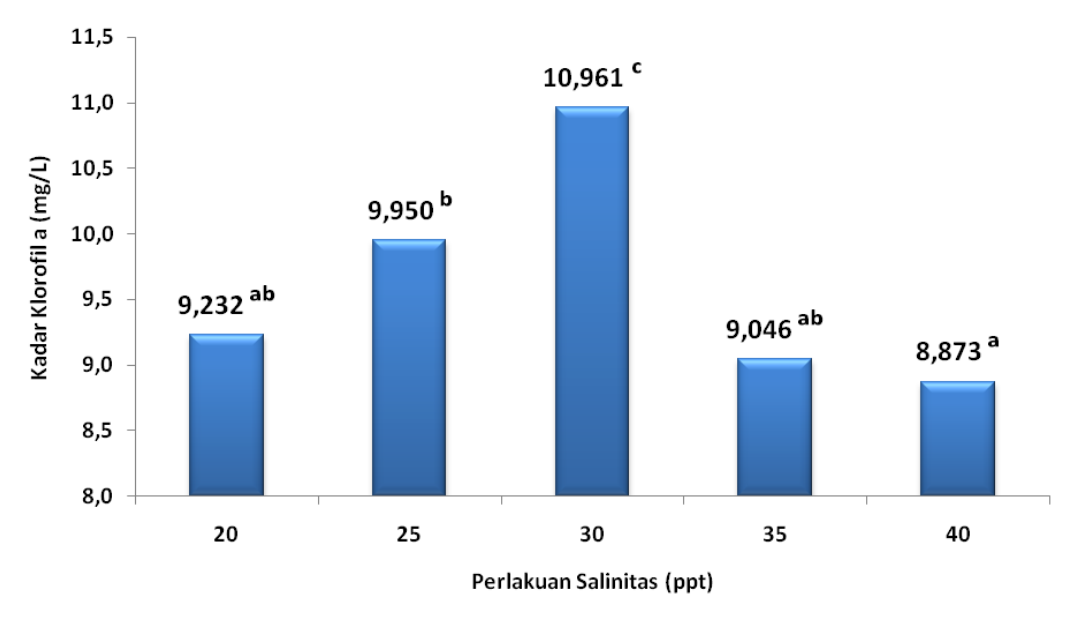

Gambar 8. Kadar klorofil a mikroalga $D$. salina pada perlakuan perbedaan salinitas.

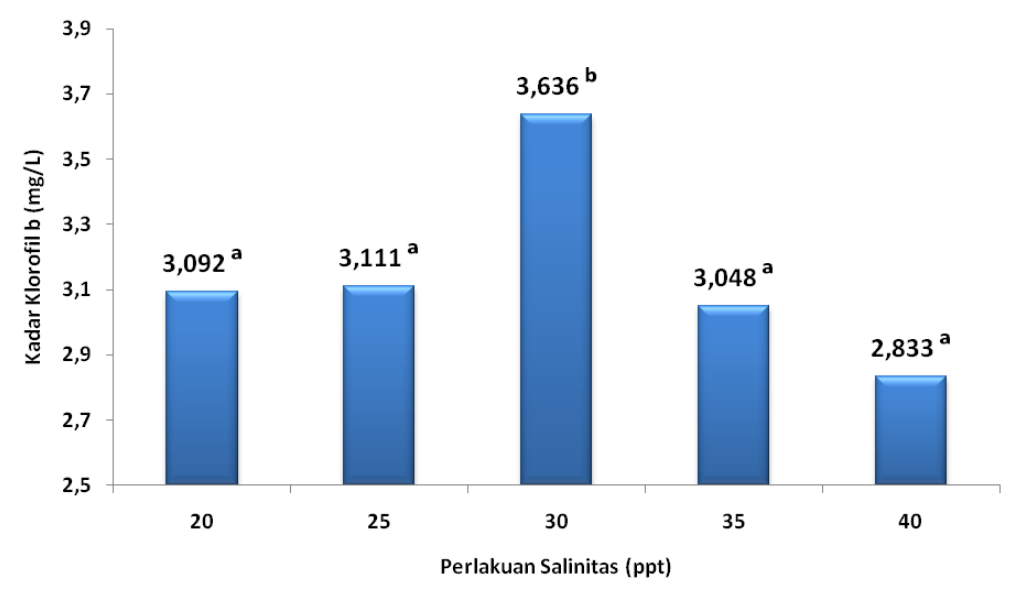

Gambar 9. Kadar klorofil b mikroalga $D$. salina pada perlakuan perbedaan salinitas. 


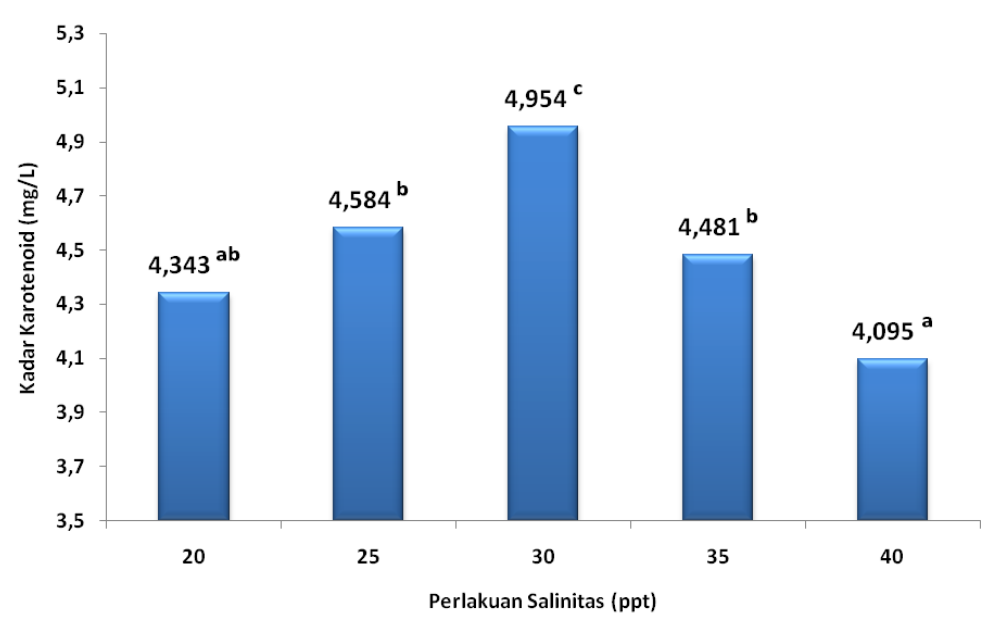

Gambar 10. Kadar karotenoid mikroalga $D$. salina pada perlakuan perbedaan salinitas.

Berdasarkan gambar 8, 9 dan 10 menunjukkan bahwa perlakuan salinitas 40 ppt memiliki kadar klorofil a, b dan karotenoid terendah dengan nilai $8,873^{\mathrm{a}} ; 2,833^{\mathrm{a}}$ dan $4,095^{\mathrm{a}} \mathrm{mg} / \mathrm{l}$ sedangkan perlakuan dengan kadar klorofil $\mathrm{a}, \mathrm{b}$ dan karotenoid tertinggi adalah salinitas 30 ppt yaitu sebesar $10,961^{\mathrm{c}} ; 3,636^{\mathrm{b}}$ dan $4,954^{\mathrm{c}} \mathrm{mg} / \mathrm{l}$. Naiknya salinitas akan menghambat proses fotosintesis Mironyuk dan Einer (1986), proses respirasi serta menghambat pembentukan sel anakan. Naiknya salinitas berpengaruh baik terhadap fotosintesis maupun respirasi, yang mana salinitas berpengaruh lebih besar terhadap fotosintesis daripada respirasi (Soeder and Stengel, 1974).

\section{KESIMPULAN}

Berdasarkan data laju pertumbuhan, kadar klorofil a, b dan karotenoid maka dapat diketahui bahwa salinitas 30 ppt yang paling optimal untuk melakukan kultur dalam usaha produksi biomassa dan biopigmen sebagai agen antioksidan

\section{UCAPAN TERIMAKASIH}

Penulis mengucapkan terimakasih kepada LPPM UNISNU Jepara yang telah memberikan biaya penelitian dalam program penelitian reguler universitas. Selain itu juga, mengucapkan terimakasih kepada Program Studi Budidaya Perairan UNISNU Jepara atas kesempatan yang diberikan kepada penulis untuk dapat mengerjakan penelitian ini. 


\section{DAFTAR PUSTAKA}

Adenan, N.S., F. Md. Yusoff, M. Shariff. 2013. Effect of Salinity and Temperature on the Growth of Diatoms and Green Algae. Journal of Fisheries and Aquatic Science, 8(2): 397-404.

Amini, S. dan R. Susilowati. 2010. Produksi Biodiesel dariMikroalgaBotryococcusbraunii. Squalen, 5(1).

Dhanam, D. S., dan K. Dhandayuthapani. 2013. Optimization of $\beta$-Carotene Production by Marine Microalga Dunaliellasalina.International Journal of Current Microbiology and Applied Sciences, 2(3):37-43.

Erlina, A. 2007. Produksi Pakan Hidup. (Pelatihan Pembenihan Udang). Laboratorium Pakan Alami, Balai Besar Pengembangan Budidaya Air Payau Jepara.

Gu, Na., Q. Lin, G. Li, Y. Tan, L. Huang, J. Lin. 2012. Effect of Salinity on Growth, Biochemical Composition and Lipid Productivity of Nannochloropsisoculata CS 179. Eng. Life Sci., 12(5):1-7.

Gunawan dan Mulyani. 2004. Ilmu Obat Alam (Farmakognosi) Jilid I. Jakarta : Penebar Swadaya. Hal 98-105.

Hirata H, Andarias I, dan Yamasaki S. 1981. Effect of salinity temperature on the growth of the marine phytoplankton Chlorella saccharophila. Mem. Fac. Fish. Kaghosima Univ. $30: 257-262$.

Huang, W.W., B.Z. Dong, Z.P. Caidan S.S. Duan. 2011. Growth Effect on Mixed Culture of Dunaliellasalina and Phaeodactylumtrucornutum Under Different Inoculation Densities and Nitrogen Concentrations. Afr. J. Biotechnol., 10:13164-13174.

Imron, M.A., Sudarno dan E.D. Masithah. 2016. Pengaruh Salinitas Terhadap Kandungan Lutein pada Mikroalga Botryococcus braunii. Journal of Marine and Coastal Science., 5(1).

Isnansetyo, A dan Kurniastuty. 1995. Teknik Kultur Phytoplankton dan Zooplankton; Pakan Alami untuk Pembenihan Organisme Laut. Penerbit Kanisius. Yogyakarta.

Mironyuk VI, Einor LO. 1986. Oxygen Exchange and Pigment Content in Various Forms of DunaliellasalinaTeod. Under Conditions of Increasing NaClContent. GidrobiolJ., 4:23-29.

Pisal, S. Dipak and S. S. Lele. 2005. Carotenoid Prodution from Microalga, Dunaliella Salina. Indian Journal of Biotechnology, 10(4):476-483.

Rusyani, E., 2001, Pengaruh Dosis Zeolit yang Berbeda terhadap Pertumbuhan Isochrysis galbana Klon Tahiti Skala Laboratorium dalam Media Komersial. Skripsi. Institut Pertanian Bogor, Bogor. 53 hlm.

Soeder, C. and E. Stengel. 1974. Physicochemical Factors Affecting Metabolism and Growth Rate. In : "Algal Physiology and Biochemistry". (W.D.P. Stewart. Editor).Blackwell Scientific Publication. Oxford London Edinburgh Melbourne : 714-730.

Vo, Trung and Duc Tran. 2014. Carotene and Antioxidant Capacity of Dunaliellasalina Strains. World Journal of Nutrition and Health, 2 (2):21-23. 
Yudiati, E., Widianingsih, R. Hartati, H. Endrawati dan R. Fahmi. 2010. Pengaruh Salinitas terhadap Kandungan Total Lipid pada Mikroalga Nanno chloropsis sp.Dalam:Prosiding Biodiversitas dan Bioteknologi Sumberdaya Akuatik. UNSOED, Purwokerto, pp. 554-558

Zhila, N.O., G.S. Kalacheva, and T. G. Volova. 2010. Effect of Salinity on The Biochemical Composition of The Alga BotryococcusbrauniKutz IPPAS H-252. J ApplPhycol., Springer, DOI: 10.1007/s10811-010-9532-8. 